\title{
$17: 38087371-38084961$
}

National Cancer Institute

\section{Source}

National Cancer Institute. 17: 38087371-38084961. NCI Thesaurus. Code C42407.

Physical location of GPR2_Gene 